\title{
Cloud Computing and Undergraduate Researches in Universities in Enugu State: Implication for Skills Demand
}

\author{
Omeh Christian \\ Department of Computer and Robotics Education University Of Nigeria \\ christian.omeh@unn.edu.ng
}

\begin{abstract}
This study identified the perceived influence of cloud computing in undergraduate researches in universities in Enugu state, Nigeria. Four objective and research questions were formulated to guide the study. The population for the study was 135 third and final year computer education students in University of Nigeria, Nsukka and Enugu State University of Science and Technology in Enugu state Nigeria. A structured questionnaire of 37 items was used to collect data and was validated by three experts. Data were analyzed using mean and standard deviation. The findings of the study revealed that using cloud Skype for online lectures makes choice of project topic difficult, while using YouTube for online video makes choice of project topic clearer. Cloud computing services make Information upload easier, however, using cloud service to enroll for online courses decreases cost of project researches. This study therefore, recommended that cloud computing should be encouraged by the government and school Management for their student and staff for academic researches, while increasing funds for procuring facilities for effective cloud computing, and for training of students/lectures for appropriate skill acquisition
\end{abstract}

Keywords: Cloud Computing, Perception, Research, Undergraduate, skill demand.

\section{Introduction}

Research is defined as the creation of new knowledge and/or the use of existing knowledge in a new concepts, methodologies and understanding. It could include synthesis and analysis of previous research to the extent that it is new and creative (Australian Research Council ERA, 2012). When a solution to any educational challenge is sought is referred to educational research. Research includes asking questions and finding out the answers, looking into something, looking for something, comparison and contrast of issues (Lifelong, 2009). Research is a process of steps used to collect and analyze information to increase our understanding of a topic or issue. These steps according to Creswell (2008) include posing a question, collection of data to answer the question, and presenting an answer for the question.

Research results are normally part of the end product of any university Education. In the university, researches can take either at undergraduates' level or post graduate level. This study dwelt on undergraduate researches in the universities in Enugu State, Nigeria.
Merkel (2003) describes undergraduate research as a partnership between students and their mentors through which students apply knowledge gained in the classroom to explore new problems and increase intellectual capacity. Most of the undergraduate students conduct research by teams (Doerschuk, 2004).

An undergraduate study exposes students to the conventions of research through practice and acquires valuable skills. The undergraduate student understands the research process, how scientists work on problems, learn lab techniques, develop skills in the interpretation of results, analyze data and integrate theory and practice (Petrella \& Jung 2008). However, over the years it has been observed that undergraduate encounter some challenges in the area of choosing research topic, data collection and analysis, storage and retrieval of materials. They spend a lot of time and resources in carrying out their researches, while some times, students leave with the view that research is not interesting and tedious and they will rather copy a work that has been done before instead 
of carrying out a novel research. Data collection, analyzes and storage are sometimes a challenge to undergraduate research as procedure and methods involved are somewhat difficult to apply (Data Collection and Sampling OPRE 6301, 2017). More so, If data collection is not properly done, it will be difficult to answer research questions in a relevant way (Chaleunvon, 2009).

Nevertheless, if data collection and analysis are done with, it is important to store the result for future use. A storage device is used in the computers to store data. It provides one of the core functions of the modern computer. They are different types of storage primary storage, secondary storage, tertiary storage, and Off-line storage, primary Storage also known as main memory. In recent times, storage is longer only done with physical device but stored in the cloud normally know as cloud computing.

Cloud computing which is an emerging technology which relies on existing technology such as Internet, virtualization, grid computing (Saju 2012). Cloud computing is a solution to problem of memory as it provides required infrastructure, software and storage device. Cloud computing is a natural evolution of the Internet, requiring careful consideration and planning, Cloud computing transforms once-expensive capital assets like disk storage and processing cycles into a readily available, affordable commodity (Cisco IBSG, 2009). Cloud computing is a storing mechanism that allow access from users to store from any device provided that user subscribe to the services through the internet. Cloud computing is flexible, and gives room for ease access to information from any device that is connected to the internet via the cloud. Cloud computing uses the mechanism called cloud storage.

Cloud storage means the storage of data online in the cloud, wherein a data is stored in and accessible from multiple distributed and connected resources that comprise a cloud. Accenture (2011) defines cloud computing as "the dynamic provisioning of IT capabilities (hardware, software, or services) from third parties over a network". Examples of Cloud Storages are Google Drive, Flickr, and Microsoft Sky Drive (Computing basics CSCA0101, 2017).

Cloud storage is mostly used because of the shortcomings of the primary storage, secondary storage, tertiary storage, and off-line storage such as data corruption, small memory capacity and erratic power supply. These loop holes affect research results. Some of the benefits offered by cloud computing in education and research include ondemand access to online database repositories, e-learning platforms, digital archive, portals, research applications and tools, file storages, e-mails and other educational resources anywhere for faculty, administrators, staff, students and other users in university (Mehmet \& Serhat , 2011). Cloud computing model has become tremendously popular due to its benefits to undergraduate students such as cost-effectiveness, scalability, usefulness, ease of use and worldwide accessibility (Nicholson 2012). Another benefit of cloud computing since it offers a large memory for data storage and effective retrieval of information.

Cloud computing is one recent technology being used by students in universities, because it aids the students in their researches. Undergraduate Students gain a lot with this model as the technology makes a convenient mobile storage space. University Students in Enugu state have started using Amazon and Google (cloud based) services in providing facilities for large research group(virtual library), access information for their assignments, online classes, group projects, creating and editing papers and presentations. Cloud computing is one of the saleable skills which is needed in the labor market because of the above advantages. Cloud computing skills become very important both in administration, education and research. Cloud computing is one the most recent mechanism in storage industry; it is one of skills demand since, Demand for well-trained skilled staff is growing worldwide and Nigeria is not an exception. Skilled labour is key to securing sustainable economic growth.

The emergence of colonial administration in Nigeria brought a type of education that is purely "academic education" which is certificate oriented. The students graduate from the university without acquiring a saleable skill, (Maduabum, 2013). Therefore, there is a disparity between skill acquired in school and skills demanded in industry. The system jeopardizes self-reliance, selfemployment and skill of Nigeria as they seek employment in civil service after graduation (Oladale, Akeke \& Oladunjoye, 2011). The world of work today expresses new skills requirements in creative and digital skills, there is rapid change in industry. Cloud computing is one of the skill demand by undergraduate student since it will aid them in industry and professional work as demand for well-trained skilled staff is growing worldwide (Kornelia, 2017). Real time data and data analytics have the potential to complement traditional labour market information systems with a timely monitoring of changing demands for skills and jobs (ILO, 2017n). Cloud computing is a new technological way of storing and managing data in the cloud. This technology is needed by research dependent industries to thrive in $21^{\text {st }}$ century. This involves a set of digital and innovation skills that should be acquired by the future workforce of any developing economy. It is therefore imperative to ensure high level of commitment to research through Cloud computing to bring about efficient results in economic developments.

\section{Statement of Problem}

Research in general is concerned with finding solution to an existing problem. Undergraduate students in Nigeria are expected to write research works (projects) at the end of their study in the university either as a group or an individual. The research work will show that the student have finally completed the study. One of the challenges in research is sourcing for information. This sometimes involves visiting the library, accessing the web, or oral interviews in order to find solution to an existing problem. The role of research is very important in the area of 
finding solution to an unsatisfactory state of an existing problem. It aids undergraduate students in developing problem solving skills and also, finds a missing link to a particular problem. Undergraduate student researchers are faced with challenges of short duration of time in carrying their research work, lack of money to provide relevant materials (text books and journals), inadequate storage medium and internet access, infrastructure and software for their research work. Some of these problems have been tackled through the use of some of the cloud computing platform.

Cloud computing is an emerging technology and which relies on existing technology such as Internet, virtualization and grid computing, can be a solution to problems of required infrastructure, software and storage medium. This computing model has become tremendously popular due to its benefits to undergraduate students such as cost-effectiveness, scalability, usefulness, ease of use and worldwide accessibility. Undergraduate Students should gain a lot with this model as the technology makes a convenient mobile storage space. Fortunately, University Students in Enugu state have started using Amazon and Google (cloud based) services in providing facilities for large research group(virtual library), access information for their assignments, online classes, group projects, creating and editing papers and presentations. This study therefore intends to determine the perceived influence of cloud computing in undergraduate students' researches in universities in Enugu State.

\section{Purpose of the Study}

The main purpose of this study is to determine the perceived influence of cloud computing on undergraduate student's research in universities in Enugu state.

Specifically, the study sought to determine:

1. The perceived influence of cloud computing on choosing project topics for undergraduates' researches in universities in Enugu state.

2. The perceived influence of cloud computing on gathering of literature for undergraduates' researches in universities in Enugu state.

3. The perceived influence of cloud computing on data collection and analysis of undergraduates' researches in universities in Enugu state.

4. The perceived influence of cloud computing on storage and retrieval of research findings for undergraduates' researches in universities in Enugu state.

\section{Research questions}

The following research questions were used to help in the study:

1) What is the perceived influence of cloud computing on choosing project topics for undergraduates' researches in universities in Enugu state?

2) What is the perceived influence of cloud computing on gathering of literature for undergraduates' researches in universities in Enugu state?

3) What is the perceived influence of cloud computing on data collection and analysis of undergraduates' researches in universities in Enugu state?

4) What is the perceived influence of cloud computing on storage and retrieval of research findings?

\section{Methodology}

Survey research design was adopted for this study. Survey research design is a research design in which a group of people or items are studied by collecting and analyzing data from only a few people or items considered to be representative of the entire group( Nworgu 2006). The study was carried out in the University of Nigeria, Nsukka and Enugu State University of Science and Technology both in Enugu state Nigeria. The population for the study was 135 computer education students comprised of 30 students from University of Nigeria and 105 students from Enugu state university of science and technology. A structured questionnaire consisting 37 items with a four-point response scale of Strongly Agree (SA), Agree (A), Disagree (D) and Strongly Disagree (SD) with 4,3,2 and 1 respectively was used for the study. One hundred and thirty five copies of the questionnaire were administered on the students and all the copies were retrieved and analyzed using mean and standard deviation. Any item with mean rate of 2.50 and above was agreed to as a the students perceived influence of cloud computing on undergraduate researches, while any item with a mean rating less than 2.50 was not regarded as a perceived influence.

\section{Results}

\section{Research Question 1}

What is the perceived influence of cloud computing on choosing project topics for undergraduates' researches in universities in Enugu state?

Data collected and analyzed to answer this research question is presented in Table (1).

Table (1). Mean and standard deviation of perceived influence of cloud computing on choosing project topics for undergraduates' researches in universities in Enugu state.

\begin{tabular}{lllll}
\hline $\mathbf{S}$ & Items & Mean & S.D & Decision \\
/ & & & & \\
\hline 1 & $\begin{array}{l}\text { Use cloud Skype for online } \\
\text { lectures makes choice of } \\
\text { project topic difficulty. }\end{array}$ & & & \\
2 & $\begin{array}{l}\text { Use YouTube for online video } \\
\text { makes choice of project topic } \\
\text { clearer. }\end{array}$ & 3.32 & 0.91 & Agree \\
3 & $\begin{array}{l}\text { Read educational material via } \\
\text { cloud help in chosen project } \\
\text { topic. }\end{array}$ & & & \\
4 & $\begin{array}{l}\text { Use cloud service to access } \\
\text { online library makes chosen }\end{array}$ & & 0.74 & Agree \\
\end{tabular}


project topic tedious

5 Cloud computing services $3.34 \quad 0.71 \quad$ Agree make upload Information easier.

6 Use cloud service to enroll for $2.63 \quad 1.02 \quad$ Agree online courses increases cost of project topic.

7 Use cloud service to buy books $3.20 \quad 0.66 \quad$ Agree online makes choice of project topic easier.

8 Cloud service makes choice of $2.93 \quad 0.81 \quad$ Agree project topic easier. Cluster Details

$2.99 \quad 0.84 \quad$ Remarks

KEY: Mean, $\mathbf{A}=$ Agree, $\mathbf{S D}=$ Standard deviation, $\mathbf{D}=$ Disagree

From the data in Table 1, it is shown that all the items except item 4, had a mean above the benchmark of 2.5, Therefore, majority of the respondents perceived that the information on item $1,2,3,5,6,7,8$ are the students perceived influences of cloud computing on choosing project topics for undergraduate students researches.

The table further reveals that item 4 , having a mean value of 2.46 fell below the cut-off point of 2.5. This show that the student perceive that access to online library do not make choosing project topic tedious.

The standard deviation values ranged from 0.66-1.07. This showed that, the respondents were close to one another in their responses and their opinions are not varied.

\section{Research Question 2}

What is the perceived influence of cloud computing on gathering of literature for undergraduates' researches in universities in Enugu State?

Data collected and analyzed to answer this research question is presented in Table 2

Table. (2)Mean and Standard Deviation of perceived influence of cloud computing on gathering of literature for undergraduates' researches in universities in Enugu State.

\begin{tabular}{|c|c|c|c|c|}
\hline $\mathbf{S} / \mathbf{N}$ & Items & Mean & S.D & Decision \\
\hline 9. & $\begin{array}{l}\text { Use cloud mode makes literature } \\
\text { gathering faster }\end{array}$ & 2.81 & 0.78 & Agree \\
\hline 10 & $\begin{array}{l}\text { Use Google Scholar for gathering } \\
\text { of information minimizes error. }\end{array}$ & 3.13 & 0.82 & Agree \\
\hline 11. & $\begin{array}{l}\text { Using cloud services is expensive } \\
\text { in gathering of information than } \\
\text { using open source. }\end{array}$ & 2.48 & 0.74 & Disagree \\
\hline 12 & $\begin{array}{l}\text { Use Google Scholar for gathering } \\
\text { of information increase data } \\
\text { redundancy. }\end{array}$ & 2.62 & 0.81 & Agree \\
\hline 13 & $\begin{array}{l}\text { use my Smartphone to gather } \\
\text { information is more expensive in } \\
\text { gathering literature }\end{array}$ & 2.52 & 1.13 & Agree \\
\hline 14 & $\begin{array}{l}\text { use my laptop to gather } \\
\text { information is faster in gathering } \\
\text { literature }\end{array}$ & 2.90 & 0.73 & Agree \\
\hline 15 & $\begin{array}{l}\text { use my tablet to gather } \\
\text { information reduce cost of } \\
\text { gathering literature }\end{array}$ & 2.67 & 1.07 & Agree \\
\hline 16 & $\begin{array}{l}\text { use my desktop to gather } \\
\text { information is not possible via } \\
\text { cloud mode. }\end{array}$ & 2.55 & 1.11 & Agree \\
\hline & Cluster Details & 2.71 & 0.90 & Remarks \\
\hline
\end{tabular}

The data in Table (2) shows that all the items except item 11, had a mean above the benchmark of 2.5 , Therefore, majority of the respondents perceive that the information on items $9,10,12,13,14,15,16$, are the students perceived influences of cloud computing on literature gathering for undergraduate researches.

The table further reveals that item 11 , having a mean value of 2.48 fell below the cut-off point of 2.5 . This showed that the student perceive that using cloud services is expensive in gathering of information than using open sources.

The standard deviation values ranges from $0.74-1.13$. This showed that, the respondents were close to one another in their responses and that their responses opinions are not varied.

\section{Research Question 3}

What is the perceived influence of cloud computing on data collection and analysis of undergraduates' researches in universities in Enugu state?

Data collected and analyzed to answer this research question is presented in Table( 3 )

Table. (3) Mean and Standard Deviation of perceived influence of cloud computing on data collection and analysis of undergraduates' researches in universities in Enugu state.

\begin{tabular}{|c|c|c|c|c|}
\hline $\mathbf{S} / \mathbf{N}$ & Items & Mean & S.D & Decision \\
\hline 17 & $\begin{array}{l}\text { Using Google Docs saves time in } \\
\text { data collection }\end{array}$ & 2.97 & 0.92 & Agree \\
\hline 18 & $\begin{array}{l}\text { Use of Google talk for class } \\
\text { discussion aid data collection }\end{array}$ & 3.27 & 0.59 & Agree \\
\hline 19 & $\begin{array}{l}\text { Use of Google Word press for my } \\
\text { web design help to collect and } \\
\text { analysis of data. }\end{array}$ & 2.91 & 0.53 & Agree \\
\hline 20 & $\begin{array}{l}\text { Use of Google Picasa for picture } \\
\text { editing makes collection and data } \\
\text { analysis faster. }\end{array}$ & 2.72 & 0.94 & Agree \\
\hline 21 & $\begin{array}{l}\text { Using Google Calendar for data } \\
\text { analysis saves time. }\end{array}$ & 2.70 & 1.02 & Agree \\
\hline 22 & $\begin{array}{l}\text { Use of .Net for project work } \\
\text { increases cost of data analysis }\end{array}$ & 2.66 & 0.71 & Agree \\
\hline 23 & $\begin{array}{l}\text { Use of .Net for project work saves } \\
\text { time in data analysis }\end{array}$ & 2.71 & 0.71 & Agree \\
\hline 24 & $\begin{array}{l}\text { Use of Google spread sheet is } \\
\text { tedious for data analysis }\end{array}$ & 2.61 & 0.89 & Agree \\
\hline 25 & $\begin{array}{l}\text { Using Google site makes collection } \\
\text { of information expensive. }\end{array}$ & 2.66 & 0.96 & Agree \\
\hline 26 & $\begin{array}{l}\text { Its expense buying software and App } \\
\text { for data analysis via cloud mode? }\end{array}$ & 2.85 & 0.82 & Agree \\
\hline 27 & $\begin{array}{l}\text { Use Google Docs save cost in data } \\
\text { collection. }\end{array}$ & 2.62 & 0.83 & Agree \\
\hline 28 & $\begin{array}{l}\text { use Google blogger for information } \\
\text { collection and analysis is easier. }\end{array}$ & 3.01 & 0.75 & Agree \\
\hline \multirow[t]{2}{*}{29} & use Google yahoo group for online & 2.68 & 0.89 & Agree \\
\hline & Cluster Details & 2.80 & 0.76 & Remarks \\
\hline
\end{tabular}

All the items in Table 3 had mean values above the 2.5 benchmark. The respondents perceive that the information in all the items (17-29) are the influences of cloud computing on data 
collection and analysis of undergraduates' researches. The standard deviation values ranged from $0.53-1.02$. This showed that, the respondents were close to one another in their responses and that their responses are not varied.

\section{Research Question 4}

What is the perceived influence of cloud computing on storage and retrieval of research findings for undergraduates' researches in universities in Enugu state?

Data collected and analyzed to answer this research question is presented in Table 4.

Table (4)Mean and Standard Deviation of perceived influence of cloud computing on storage and retrieval of research findings for undergraduates' researches in universities in Enugu state.

\begin{tabular}{|c|c|c|c|c|}
\hline$\overline{\mathbf{S} / \mathbf{N}}$ & Items & Mean & S.D & Decision \\
\hline 30 & $\begin{array}{l}\text { Using yandisk cloud services for } \\
\text { storing research materials reduce cost } \\
\text { of storage. }\end{array}$ & 2.71 & 0.94 & Agree \\
\hline 31 & $\begin{array}{l}\text { Using one drive cloud services for } \\
\text { backup of research material is } \\
\text { expensive. }\end{array}$ & 3.00 & 0.71 & Agree \\
\hline 32 & $\begin{array}{l}\text { Using Google drive cloud service } \\
\text { makes for easy storage of research } \\
\text { materials }\end{array}$ & 2.92 & 0.75 & Agree \\
\hline 33 & $\begin{array}{l}\text { Use of drop box cloud service for } \\
\text { storing research materials aids } \\
\text { accessibility of research materials }\end{array}$ & 2.71 & 0.78 & Agree \\
\hline 34 & $\begin{array}{l}\text { Use of mega cloud service saves } \\
\text { time in retrieval of research } \\
\text { materials. }\end{array}$ & 2.97 & 0.77 & Agree \\
\hline 35 & $\begin{array}{l}\text { Cloud computing reduces } \\
\text { unauthorized access to personal } \\
\text { information }\end{array}$ & 3.10 & 0.85 & Agree \\
\hline 36 & $\begin{array}{l}\text { Cloud storage enables easy access my } \\
\text { stored files at anytime }\end{array}$ & 2.86 & 0.86 & Agree \\
\hline \multirow[t]{2}{*}{37} & Ability to use cloud service make me & 2.53 & 0.76 & Agree \\
\hline & Cluster Details & 2.85 & 0.70 & Remarks \\
\hline
\end{tabular}

The data in Table(4) shows that all the items had mean scores above the 2.5 benchmark. This means that majority of the respondents perceive that the information on all the items are the influences of cloud computing on data storage and retrieval of research findings for undergraduates' researches. The standard deviation values ranges from $0.75-0.94$. This showed that, the respondents were close to one another in their responses and that their opinions are not varied.

\section{Discussion on the findings}

The result of the research question 1 showed that the perceptive influence of students towards cloud computing on choosing project topics for undergraduates' researches in universities reveals that Use youtube for online video makes choice of project topic clearer, Cloud computing services make upload Information easier and Use cloud service to enroll for online courses increases cost of project topic. These findings were in line Bocar (2013) findings of this study, the shift towards cloud computing would enable the universities and educational institutions to save money and take benefit of the developing technology. Both private and educational cloud can provide the necessary computational facility on demand of the user without any expense and can create a common platform for sharing the various resources from the various institutions. Adopt cloud computing as a solution to the developing technologies and try to reduce their expenses of sourcing for information (Saju, 2012).

The findings of the study of research question 2 as presented in table 2 showed perceived influence of cloud computing on gathering of literature for undergraduates' researches in universities in Enugu state. These include Using cloud service to buy books online makes choice of project topic easier, Cloud service makes choice of project topic easier, Using cloud mode makes literature gathering faster, Using Google Scholar for gathering of information minimizes error. This in line with Misra \& Pandey (2014), Digitization is an important aspect for academic libraries in 21 st century. Users of academic libraries are migrating onto the cloud for their information needs, and library services must migrate with them if those needs are to be met. Store expansive amounts of sensitive data and information that's easily accessible (Christopher \& Temitayo, 2014).

The findings of the study in Table 3 revealed that the perceived influence of cloud computing on data collection and analysis of undergraduates' researches in universities in Enugu state. Using Google Docs save time in data collection, Using Google talk for class discussion aid data collection and Using Google Word press for my web design help to collect and analysis of data. This finding is in line with the assertion of Dahunsi \& Owoseni (2015) that Cloud computing will bring a lot of development on the side of data collection, especially to the telecommunication sector and educational sector. For the sustainability of the cloud network, electricity, ICT manufacturing industries and ICT infrastructural backbone of the country has to be well established.

As shown in Table 4, the perceived influence of cloud computing on storage and retrieval of research findings for undergraduates' researches in universities in Enugu state. Use yandisk cloud services for storing research materials reduce cost of storage, use Google drive cloud service for easily storage of research materials and use drop box cloud service for storing research materials aids in accessibility of research material. Ability to use cloud service make me more professional in storing and retrieval of data. This finding is in line with the assertion of Abdulsalam \& Fatima (2011) argued that cloud computing is the solution to ICT in higher education in Nigeria. The authors identified scarcity of ICT infrastructure and lack of access, high cost of ownership, unsteady and inadequate electrical power supply as factors that are limiting the infusion of ICT in Nigeria higher education. 


\section{Implication for skills demand}

It is evident from the study that undergraduate students have positive perception of the use of cloud computing. This by implication shows that the use of cloud computing in undergraduate research is a welcomed development and should be encouraged. Academic institutions should also increase their awareness campaign so that more students will embrace cloud computing services. Undergraduate students also agree that use of cloud mode makes literature gathering faster and use of Google Scholar for gathering of information minimizes error. To this effect, academics institutions and other relevant agencies should work together to provide amenities for effective and efficient incorporation of cloud computing in the students curriculum because it is one the skills demanded in the labor market. This technology involves a set of digital and innovation skills that should be acquired by the future workforce of any developing economy like Nigeria. It is therefore imperative to ensure high level of commitment to research through Cloud computing to bring about efficient results in economic developments of our nation.

\section{Conclusions}

Cloud computing is one of a growing number of storage mechanism which aid students researches in universities. Based on the findings of this study, it was therefore inferred that the use of cloud computing in undergraduate project will release the student from the traditional means of chosen project topic, storing of the data collected and retrieval, Cloud service makes choice of project topic easier. However, the students can easily have access to information stored in the cloud, also ability to use cloud service make me more professional in storing and retrieval of data. Undergraduate student also have positive perception of the use of cloud computing in there researches, this help for effective and efficient research.

\section{Recommendation}

Based on the findings and conclusion of the study, the following recommendations were made:

1. Institution should increase the awareness of the use of cloud computing since is one of the skills demand in the field of work (employment). The awareness should be carried to both private institutions by researcher, so that students in these schools will not be disadvantaged.

2. The Government should provide ICT centers and increase power supply especially in tertiary institutions.

3. Teachers should encourage the use of cloud computing the more for their students because it increases their web presence.

4. The administration of Universities should encourage cloud computing in order to increase institution visibility in scientific research in the globe.

\section{References}

[1] Rahman, Merkel, C. (2003).Undergraduate research at the research universities. Journal of New Directions for Teaching and Learning, 93, 39-53.

[2] Doerschuk, P. (2004). A research and mentoring program for undergraduate women in computer science. Proceedings of the 34th ASEE/IEEE Frontiers in Education Conference, S2H-7 $\mathrm{S} 2 \mathrm{H} 12$.

[3] Creswell, J. W. (2009). Research design: Qualitative, quantitative, and mixed methods approaches (3rd Ed.). Thousand Oaks, CA: Sage.

[4] Institute of Lifelong Learning Organisation University of Leicester Version (2009) Retrieved on 30/7/2017 from www.nigerianobservernews.com

[5] Australian Research Council ERA, (2012) "Cloud Security," in proceedings of the 2012 IEEE International Conference on Services Computing. Washington: DC, USA, 2012, IEEE Computer Society,. 10 (8) 517-520.

[6] Data Collection and Sampling OPRE 6301(2017) Retrieved from www.jisc.ac.uk/assessment.html

[7] Skills on the move:global trends, local resonances Retrieved from http://www.ilo.org/global/topics/future-ofwork/lang--en/index.htm

[8] Accenture (2011) Application deployment Guide version 1.0. view white paper for U.S. Public Sector, 1st Edition. Retrived (2017) from http:// www.Webservice Deployment Environment SetupGuide_V1[1].v.pdf

[9] Anna c. bocar (2013). difficulties encountered by the student - researchers and the effects on their research output. Proceeding of the Global Summit on Education (GSE2013) 031, 61-66

[10] Christopher \& Temitayo (2014). The impact and challenges of cloud computing adoption on public universities in southwestern nigeriaijacsa) International Journal of Advanced Computer Science and Applications, 5 (8), 115-124

[11] CSCA0101 Computing Basics, (2017). Chapter 5 Storage Devices Retrieved May 11, 2017 from https://explorable.com/top-down-vs-bottom-upprocessing.

[12] Dahunsi \& Owoseni (2015). cloud computing in nigeria: the cloud ecosystem perspective. Nigerian Journal of Technology (NIJOTECH) 34. (1), $209-216$

[13] Dahunsi, F. M. \& Owoseni, T M. (2015). The cloud computing in Nigeria: The cloud ecosystem perspective. Nigerian Journal of Technology (NIJOTECH) 34 (1), 209-216

[14] Katz, E., \& Coleman, M. (2001). Induction and mentoring of beginning researchers at academic colleges of education in Israel. Mentoring and Tutoring, 9 (3), 223-239 
[15] Mehmet \& Serhat (2011), Cloud Computing for Distributed University Campus, International Conference on the Future of Education, Pixel Publishing International,

[16] Misra and pandey (2014) . Digitization of library materials in academic libraries: issues and challenges.Journal of Industrial and Intelligent Information 2 (2),4-8

[17] Nnadozie C.E (2008). Cloud computing in Nigeria. Unpublished M.Sc. Project. Department of computer science University of Nigeria, Nsukka.

[18] Nworgu, B. G. (2006). The indispensability of ICT in educational research. Information and Communication Technology in the Service of Education, 1-10.

[19] Saju, M. ( 2012). Implementation of cloud computing in education. A Revolution International Journal of Computer Theory and Engineering, 4 (3), 1-6

[20] Skills on the move: global trends, local resonances (2017) retrieved on feb. 122018 from http://www.ilo.org/global/topics/future-ofwork/lang--en/index.htm

[21] Cloud Computing in the Public Sector: Public Manager's Guide to Evaluating and Adopting Cloud Computing(2009) retrieved from www.cisco.com/go/offices.

[22] Nicholson. J. L. (2012) Cloud Computing: Top Issues for Higher Education. [Online]. Available:http://www.universitybusiness.com/arti cle/cloud-computing-top-issues-highereducation/page/0/3

[23] Kornelia Haugg (2017) UNESCOUNEVOC Shanghai Consensus on TVET. $\begin{array}{llll}\text { retrieved on } & \text { Feb. } & 12 & 2018\end{array}$ fromhttps://ec.europa.eu/epsc/sites/epsc/files /strategic_note_issue_13.People's Republic of China 4 - 6 July

[24] Maduabum M.A (2013) reflection on current trend in science and technology in relation to the attainment of Nigeria vision 2020. A lead paper presented at the maiden conference of the school of science education, federal college of education (technical) Asaba from 7-10 may 2013

[25] Oladale, P.O, Akeke, N.I and Oladunjoye (2011) Entrepreneurial development: A panacea for unemployment reduction in Nigeria. Journal of emerging trend in economics and management science (JETEMS) 2, (4), 251-256

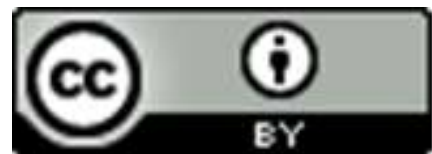

